\title{
SPORTS PHOTOGRAPHY AND ITS ARTISTIC DIMENSIONALITY
}

\author{
Miloš Stamenković \\ Faculty of Sport and Physical Education, University of Niš, Niš, Serbia
}

UDK 796.011.7:771

\begin{abstract}
SUMMARY
Sports photography is a powerful visual tool that can be used to promote sports, athletes and recreational physical activities. Her main role is to present sport as an art. In that respect, good sports photography also implies the recorded moment of the athlete in a specific movement position, which is unusual and which cannot be seen on television. When it comes to the promotion of professional sports, sports photography occupies a significant place in the sports press and sports magazines. On the other hand, sports photography also promotes recreational sports, which is intended for all those who want to do sports for themselves and their own health. Sports photography has the power to present important sports and recreational events to readers in a simple way, without large and dry texts. Good sports photography refers to the composition, angle, light, dynamics and color contrast, i.e. the relationship between warm and cold tones. Also, sports photography depends on good photographic equipment, knowledge and experience of a sport photojournalist. Sports photojournalists always try to present quality and interesting sports photographs in the most professional and high-quality way, which in an artristic way convey "visual information" of sports events to loyal readers and sports fans. It is very important to understand that sports photography is not only sports, but also artistic. Therefore, the aim of this paper is to present sports photography and its artistic dimension.
\end{abstract}

Key words: sports photography, art, photojournalist, recreational activity, sports, sports press, dimension. 


\section{INTRODUCTION}

Sport occupies an important place in terms of attractive events that always attract a lot of attention from spectators, both from small screens and from live stands. The explanation why sport, as an attractive manifestation, arouses interest, lies in its diversity and complexity. Sport is characterized by different movement forms that differ both in aesthetics and in the coordinated activity of the upper and lower extremities, i.e. by neuromuscular coordination. Due to the different moving, simple and very complex shapes, sport is extremly complex to understand. The very complexity of sports requires top professional athletes to be in extremely good sports shape. Depending on the difficulty of motor tasks, the athlete must be biomechanically, physiologically-biochemically and psychologically prepared in order to successfully do everything that is expected of him.

Based on all of the above, it is clear why sport arouses great attention and interest of the audience. Every movement made by an athlete in different movement poses, with different mechanical activity of skeletal muscles, delights the audience. This analysis of movement prerformance, with the effect of muscle force, body weight and gravity, in simple and very complex movement poses, arouses the interest of sports photography and sports photojournalists. Sports photography aims to capture a moment that depicts sport as an art. Analyzing the different movements of the athlete, it can be said that he is an artist, who shows himself as an artist with his various movements. So, the correlation between art and sports is high thanks to sports photography and experienced sports photojournalists.

Taking a good sports photograph with good composition and lighting is a challenge. In order to make a good sports photograph with good composition and lighting, the highest quality equipment that can meet high standards, is necessary. Secondly, a good knowledge of sports, along with experience, significantly affects the photo shooting of quality sports photos. And thirdly, it is necessary to find those angles from which it will be possible to make such photographs that will be original and different from the photographs published so far. Also, the conditions in which sports photojournalists find themselves, should be mentioned. When we talk about conditions, we primarily mean on outdoor and indoor spaces. Now, the question arises, what is the difference between taking photographs in outdoor and indoor spaces? To understand the difference, it is necessary to briefly explain the effects of light on the guality of photographs.

When photographing in indoor spaces with very low lighting, it is necessary to set a certain parameter that will help the photojournalist to "freeze" the movement of the athlete. ISO is a parameter that can be adjusted to record fast movements of athletes in indoor spaces. The higher its value, the greater is the possibility of catching unusual moment in sports. It should also be noted that, the 
higher the ISO value is, the quality of the captured photos is lower. This fact applies, above all, to photographs taken with a high ISO value in indoor spaces, with very low lighting. On such photographs taken, small dots apear that significantly affect the sharpness and the quality of the photographs.

The explanation can be found in the weak photographic equipment with a higher aperture value. The ideal value of the aperture for neutralizing these tiny dots is f 2.8. Anything above that value leads to a deterioration in the quality of sports photographs taken in indoor spaces with extremely low lighting. Based on the above facts, the logical conclusion is that light plays a very important role in making good sports photographs, in addition to the quality of the photographic equipment itself. When it comes to outdoor space, the situation si better for making better sports photographs. Naturally obtained light with the help of the sun, directly affects the creation of quality sports photographs. In this case, when the light is at a satisfactory level, the aperture is not of great importance, nor is the high value of the ISO parameters.

Too much sunlight can create shadows on the faces of athletes, which can affect the quality of the obtained photographs. There is also a risk of backlighting, which can impair the quality of the photographs. So, in this case, it is necessary to use natural light wisely and skillfully in order to achieve results, and that is good sports photograph. The best light for taking quality sports photographs in outdoor space should be neither strong nor weak. The best ally for such light are clouds, because they diffuse light, making it ideal for photografing. This means that the light is soft enough and not too sharp. However, we should not ignore the fact that the weather is variable, which means that the ideal conditions for photographing sports events can lead to unfavorable conditions such as rainy, cloudy and cold weather. In any case, a good result is achieved with good photographic equipment and conditions in which the photographing is realized (outdoor and indoor spaces).

Being a sports photojournalist is not easy for several reasons. One of the reasons lies in the fact that a photojournalist who takes pictures for a certain sports or news agency, must be in outdoor or indoor spaces all the time.

Secondly, the moment when the image should be forwarded to the editorial office, demanding speed and responsible role, because any delay leads to negative reactions from the editor. Third, sports photography reguires a large monetary sacrifice for a good photographic equipment consisting of several photographic lenses, camera bodies and a flash. On the other hand, photojournalists convey the "magic and art" of sports through sports photography. By analyzing such a photograph, we can see not only the athletes' struggle for victory, but also their emotional and mental profile. This means that sports photography also analyzes the psychological profile of athletes when they win and when they lose. This is 
certainly an interesting detail for daily newspapers and sports press, as well as for the readers.

In addition to showing sports events, sports photography also aims to show sports as an activity that can have a positive impact on human health. Unlike professional sports in which the goal is to win and only win and which reguires great sacrifice and exceptional efforts, amateur sports give everyone a chance to be active. Amateur sports are mainly intended for all those who want to enjoy in sports. The only thing that amateur sport requires from participants is to enjoy in the chosen activity without insisting on great efforts and results. The basic principles on which amateur sport is based, are contained in providing an opportunity for a person to realize his need for society, sports progress, with a good acceptance of the process of rules of behaviour and the appropriate sports character of training. ${ }^{1}$ Sports photography also shows amateur sports in which all those who have decided to introduce into their lives physical activity that activate the locomotor system and the functional work of the organism as a whole participate.

In the end, it can be said that sports photography occupies a significant place in the sports press and internet portals. It shows sports in a way that is completely different from showing sports and sports events on television. The aim of this paper is to theoretically present the importance of sports photography and its artistic dimensionality.

\section{DEFINITION OF SPORTS PHOTOGRAPHY}

Sports photography refers to a genre of photography that covers all types of sports. In most cases, professional sports photography is a branch of photojournalism. ${ }^{2}$

Sports photography is a branch of photography that aims to capture those specific sports actions of athletes that are realized in specific and unusual situations. Sports photography fulfills the task given to it: to capture and "freeze" the movement of an athlete in an unusual moving position with expressed emotions that can be positive (victory) and negative (defeat, injury, etc.). Every sporting moment that is captured, remains lasting thanks to a skilled sports photojournalist. So, based on the definition, it can be said that sports photography shows sport and its actors in a different and specific way, that is, athletes. Just

\footnotetext{
1 Према: Ненад Живановић, и др., Теорија физичке културе.....стр. 264.

2 https://en.wikipedia.org/wiki/Sports_photography
} 
performing the movement, and above all complex by top athletes, is amazing. It is even more valuable, if the camera managed to capture such a moment. As it was said, photography not only records biomechanical changes of the body in space and time, but also emotional reactions. All of the above makes it even more difficult to create the right definition of sports photography.

Sports photography differs from other branches of photography in that it unites all those branches on which photography rests. For example, there is a special branch of photography that is aimed at capturing portraits, landscapes, architecture, etc. Sports photography, if analyzed accurately and studiously, encompasses all of the above. So, we are talking about the very complexity of sports photography, which is why really hard to give the right definition of sports photography.

Sports photography is a visual and artistic presentation of professional and recreational sports, as well as active participants in it. Thanks to sports photography, readers will follow sports and sports evente in a different and artistic way.

Figure 1. Artistic representation of football through sports photography.

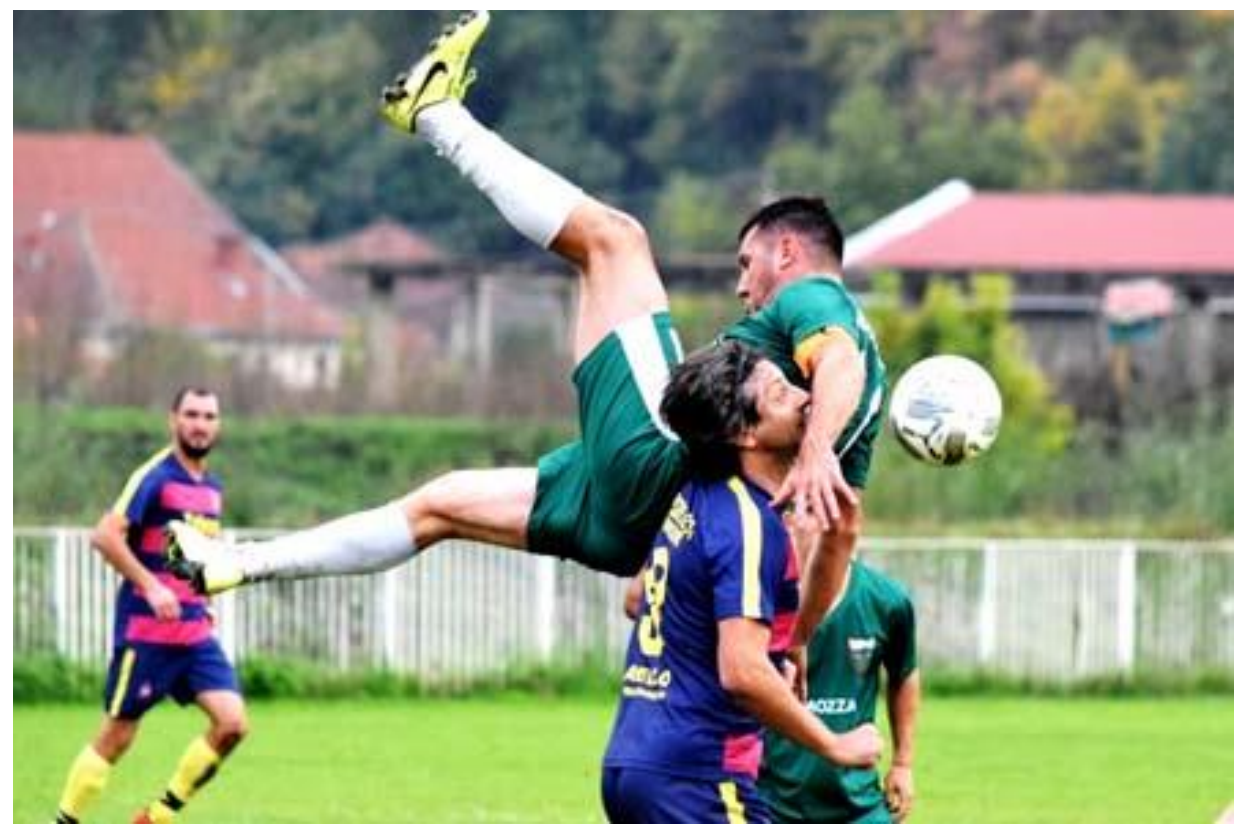

Legend: Football ballet in Zone South FS RIS: Radan (Lebane)-Svetlost (Badnjevac). Photo: Miloš Stamenković. 
Analyzing this photograph, we can say that sport is really a great challenge for both athletes and sports photojournalists. This picture is the best example of how complicated it really is to make a shot like this. In order to make such a shot, a sports photojournalist must be able to predict future action in the game. And not only that, a sports photojournalist must be in the right place, which makes it even more difficult to get a photograph like this, because it is not known where such an attractive action will take place. So, in addition to good photographic equipment and knowledge, luck is also necessary. In conclusion, it can be said that sports photography is a newspaper, sports and artistic branch of photography that conveys sports events to readers in a visual and attractive way.

Sports photography shows not only the better side of sports, but also the negative. The negative side of sports is reflected in the fact that we have an increasing frequency of using doping in order to achieve top sports results or break world records. Sports photography also shows athletes who use illicit drugs (doping) as well as the health consequences that result from the use of doping.

Unfortunately, sports photography shows readers the deaths of athletes, as well as unpleasant sports events that lead to incidents and serious sports injuries. Such scenes are really ugly and difficult to watch and analyze, bit it is an integral part of sports photography and photojournalism.

In the end, it can be concluded that sports photography, visually and artistically, shows all the positive and negative sides of professional sports. Also, it should be kept in mind that sports photography is a powerful tool that can be used in the popularization of recreational sports, i.e. selected physical activities.

It is true that photography speaks more than a thousand words, which means that attractive sports photography can certainly influence the initiation of an intrinsic motivation of a person to engage in freely chosen physical activity. Thus, the goal of sports photography is multiple: a) to popularize professional sports and their athletes through sports and commercial photography; b) to show all the positive and negative sides of top sports; c) to present sports as amateur and recreational, which is intended for everyone regardless of age and gender, and in that way to motivate people to be phyisically active for their own health, and not for results.

\section{METHOD OF WORK}

The subject of this research is sports photography and its artistic dimension.

The aim of this paper was to theoretically explain the role of sports photography not only through journalism, but also through the artistic framework. 


\section{RESULTS AND DISCUSSION}

Sports photography undoubtedly has a significant place in sports press and publicism. It's main and primary role is to present sports to the readers as art, which it is. Sport is characterized by dynamic and varied movements, and the main role of sports photography is reflected in the fact that it is in this way that sport shows its essence. ${ }^{3}$ In order to understand the artistic significance of sports photography, it is not enough to textually describe its artistic dimension, but it is desirable to show its artistic value thorugh examples of sports photography.

In this part of the paper, greater emphasis will be given to examples of sports photography, in order to better understand its purpose and artistic dimension. From the anthropological aspect, man is in fact an artistic object for sports photography, because through it all the propertises of human body are shown, in various moving and specific poses. It is about the body's ability to produce and realize those movements that require experience, work and muscle potential. Sometimes, an athlete is required to pose in front of the camera with a certain sports prop, for the cover of a well-known sports magazin or press. On the other hand, regardless of the fact that static sports photographs also have artistic value, dynamic photos, i.e. photos from various sports actions, however, have a higher value. So, every sporting moment that is captured, represents a "live view of the event", in relation to the static one, of course without diminishing the significance of such photographs.

Sports photography also occupies an important place in sport science, because human movement and motor functionality of the locomotor system are analyzed with its help, as well as with the help of a camera, that is, videos. In this way, sports scientists and scientists in the field of medical sciences gain a better understanding of the functional status of the musculoskeletal system of the locomotor system, as well as its possibilities for normal motor functionig in sports.

So, sports photography has not only artistic value, but also scientific value. From an artistic point of view, sports photography not only shows sport as art, but also shows composition, the power of light and color. When analyzing the composition, it primarily refers to the frame, which shows all the elements that are covered by the lens and photograph. Also, their mutual interaction is investigated, in order to better understand the obtained photograph. The mutual interaction is, first of all, the relations of the athlete, the props (ball, gymnastic device, etc.), and the environment (hall, football field, swimming pool, etc.). The

3 Stamenković, Miloš. Sports photography and historical development. Fizičko vaspitanje i sport kroz vekove, 2018, 5.1: 93-115. 
essence of a good composition is reflected in the good relationship of the athlete with the props and the environment, as well as with the light and color.

Figure 2. Basketball detail.

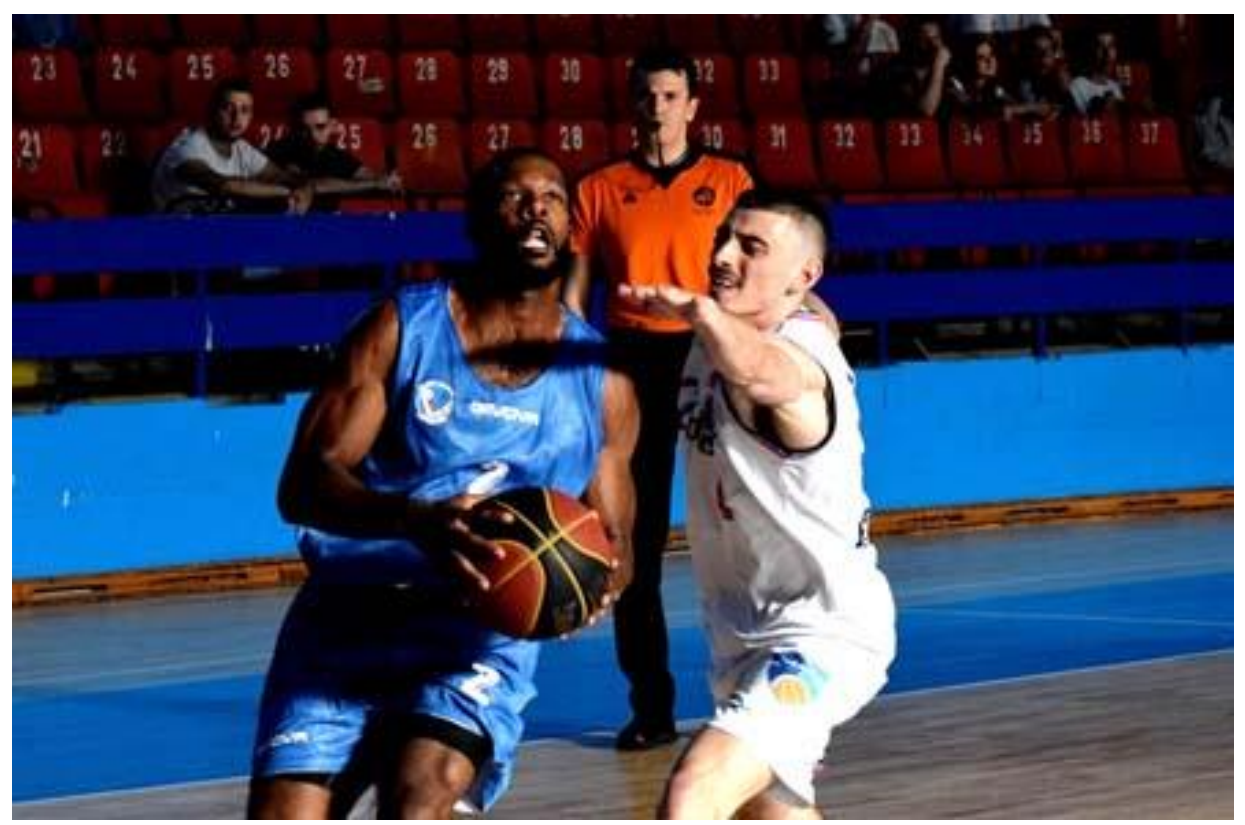

Legend: The influence of light on a dramatic depiction of a sports fight for a ball. Photo: Miloš Stamenković.

Analyzing this photo, one can see how much light plays an important role in creating quality sports photographs. Thanks to the light, this photograph shows a real dramatic fight for victory. In addition, good light helps to express the muscles of the actors, as well as their fascial reactions. This photograph confirms the thesis that good light is important for good photography. 
Figure 3. The world's first tennis player Novak Djokovic.

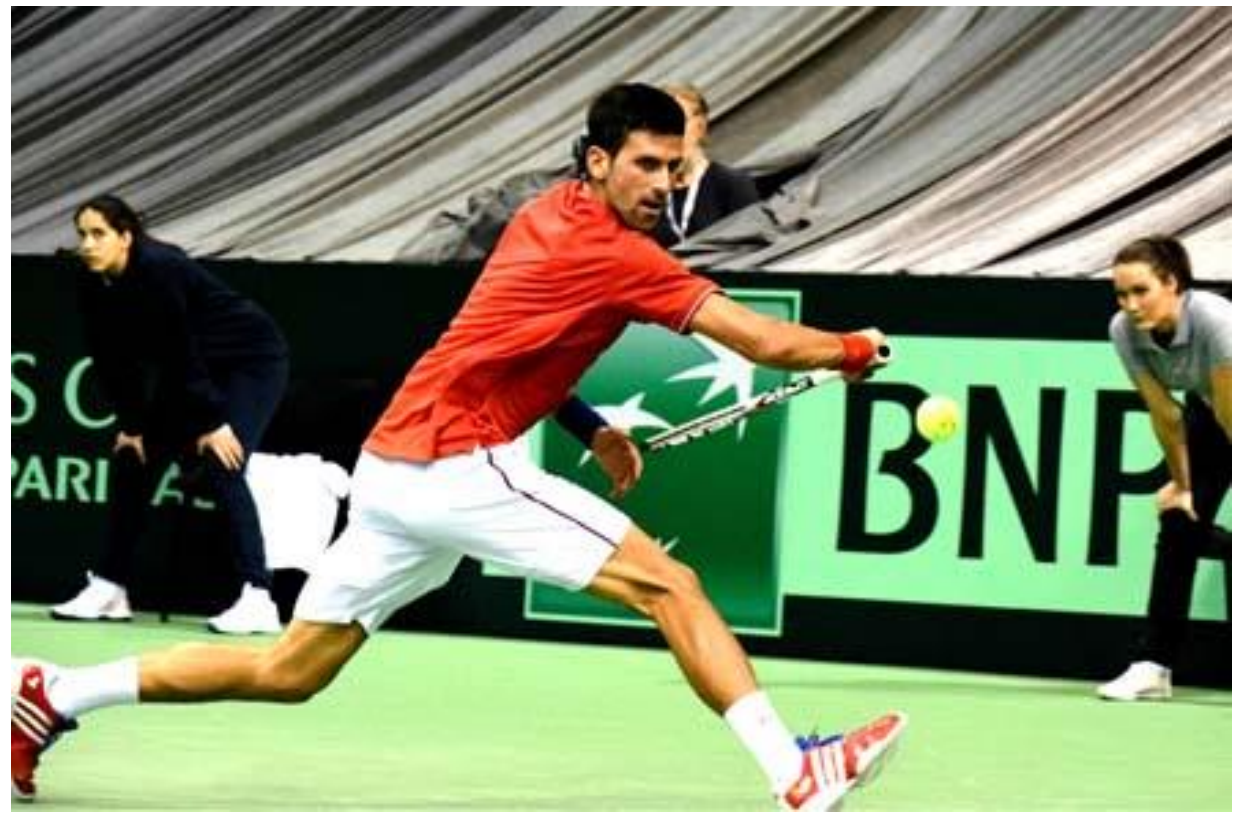

Legend: Fascinating mechanical properties of the musculoskeletal system in unusual movement situations of the world's first tennis player Novak Djokovic. Photo: Miloš Stamenković.

As it was said, sports photography aims to capture those moments that cause enthusiasm among sports fans. This photograph shows the perfection of the movement of an athlete who reached that level on the basis of many years of hard work and great talent. The analysis of this photograph shows the fascinating ability of our locomotor system, which is reflected in the successful performance of the most complicated movements with a disturbed point of support, i.e. balance. This is what sports photography is most interested in: to capture such a moment and to show it to the public in an artistic way. What adds value to this photograph is the relationship between warm and cool colors. In other words, any photograph that has strong contrasting colors significantly affects the viewer's attention, with good light and composition. In this case, elements such as composition, light, dynamics and contrast are at a satisfactory level, which means that this photograph has fulfilled its goal and task. 
Figure 4. Football scissors at the City Stadium in Leskovac.

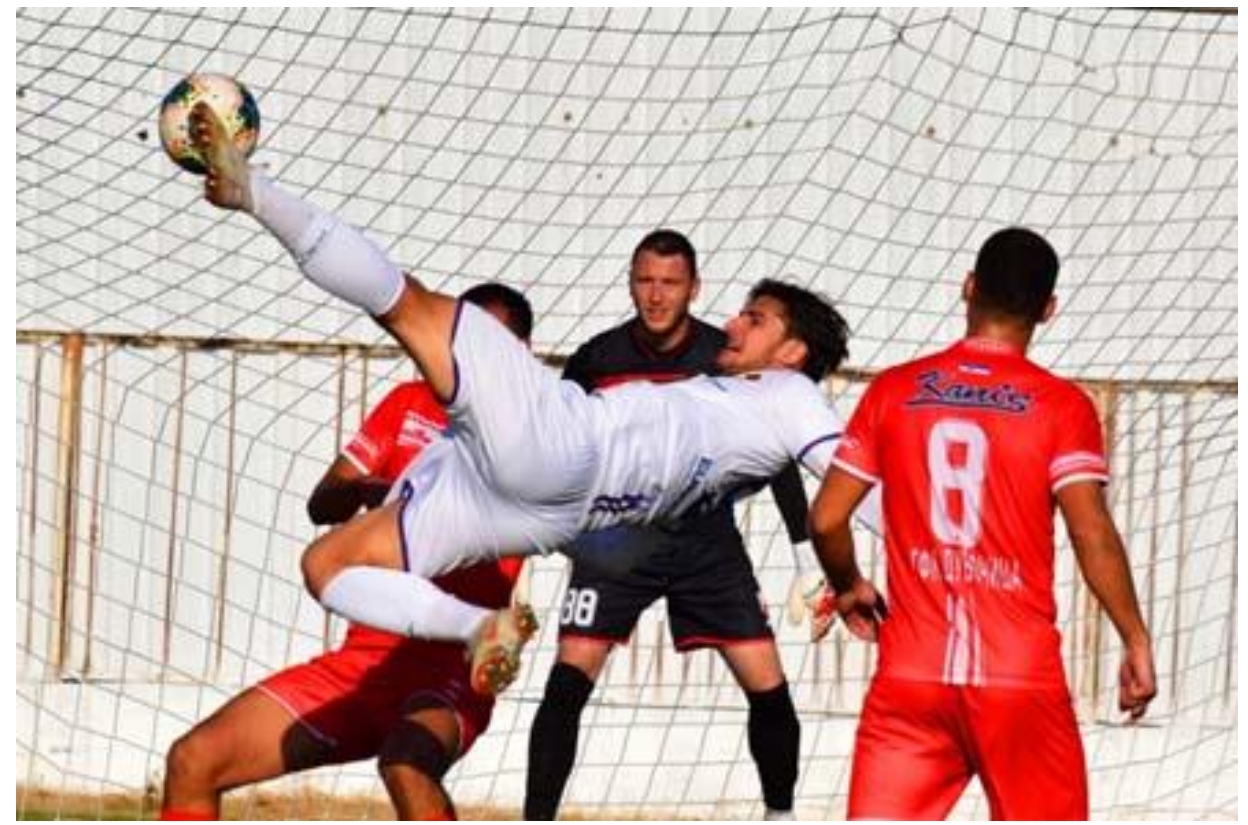

Legend: Football as an art: An attractive attempt to score. Photo: Miloš Stamenković.

When following a sporting event, a photojournalist always tries to capture those moments that may be of interest to readers and the sports press. There is always the possibility of somethnig unpredictable happening, in the sense of performing rare attractive movements such as football scissors. In order for this football mastery to be recorded, it is necessary to follow a football match with maximum concentration and good photographic equipment, in this case a lens. In any case, it is great challenge and a rarity to capture such a moment successfully. It goes without saying that photojournalist need to choose the right place and the right moment for that, with knowledge of the technical finesse of certan sports, in this case of football.

Analyzing this photograph, it can be concluded that there is a good color contrast, i.e. good relationship between warm and cool colors, good dynamics, composition and sharpness. In other words, there is a mutual interaction between the athlete, the props and the environment. This is another example of how sports photography represents sports to people in a completely different and artistic way. 
Figure 5. Leskovac swimming star Nina Stanisavljevic.

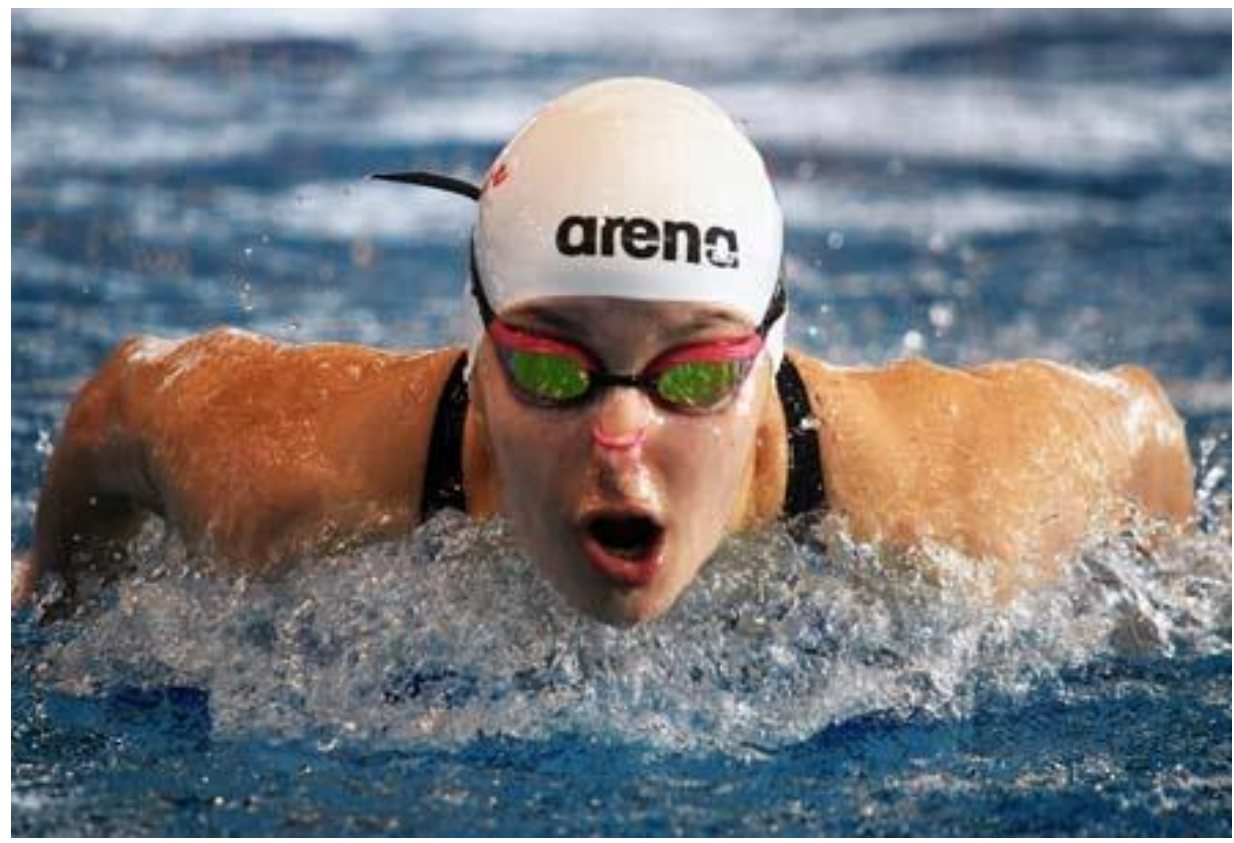

Legend: The most attractive style in swimming, butterfly, presented in the most beautiful way by the promising swimmer Nina Stanisavljevic. Photo: Miloš Stamenković.

Analyzing this photograph, it can be ssen that all the elements (composition, light, contrast, dynamics) are at a satisfactory level. Swimming is a sport that enables specific movement of swimmers, which takes place without the influence of gravity in a horizontal position. The characteristic of swimming sport is reflected in the fact that it requires good buoyancy of the body, with specific biomechanical trajectories that are determined for each swimming technique separately. In swimming, the most attractive swimming style is the butterfly, due to its motor complexity and biomechanical attractiveness of movement.

When watching swimming competitions, the task of a sports photojournalist is to capture the swimmer in his characteristic swimming style. Considering that swimming is primarily an individual sport, the focus of the apparatus should be on the individual swimmer during the race. In the analysis of swimming styles, the position of the body as well as the trajectory of a certain style, differ in relation to other swimming styles.

This difference can also affect the quality of the photographs, which means that the photojournalist must keep this fact in mind. Crawl and back style are specific for photographing, mainly due to the position of the body and the trajectory of the arms and shoulder girdle during the retropulsive phase (hand coming out of the 
water). In relation to those two swimming techniques, the butterfly and the breaststroke are in the frontal plane, which means that the photojournalists job of photographing is easier. However, for a good detail from the pool, it is necessary that the photojournalist has a good knowledge and understanding of this sport, because otherwise, he will not know and understand the movement of swimmers and will not know when to "take a picture".

Figure 6. Handball ball fight.

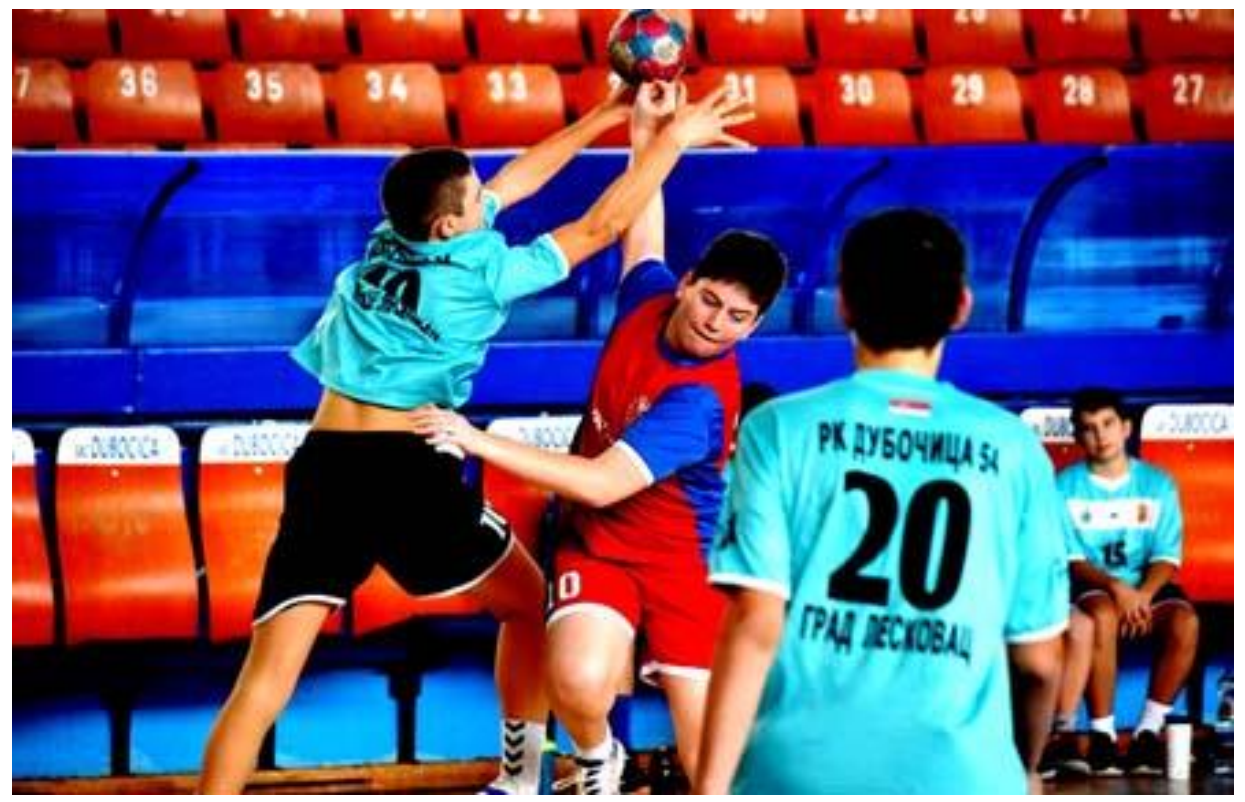

Legend: Young and talented handball players fighting for the ball. Photo: Miloš Stamenković.

Handball, as a collective sport, contains those elements of movement that can contribute to a photojournalist to take quality sports photographs. Handball attractive actions are usually those that lead to the manifestation of mechanical force of the muscles of the lower extremities, in order to produce an explosive jump.

In other words, a jump shot in handball is one of the attractive sports details, which always arouses the interest of photojournalists to capture such a moment. This photograph fully satisfies all those elements (composition, light and dynamics), which significantly affect the quality of the photograph. Also, this photograph stands out with good contrasting colors, which certainly affect the quality of the photograph. 
Figure 7. Beach handball in Leskovac.

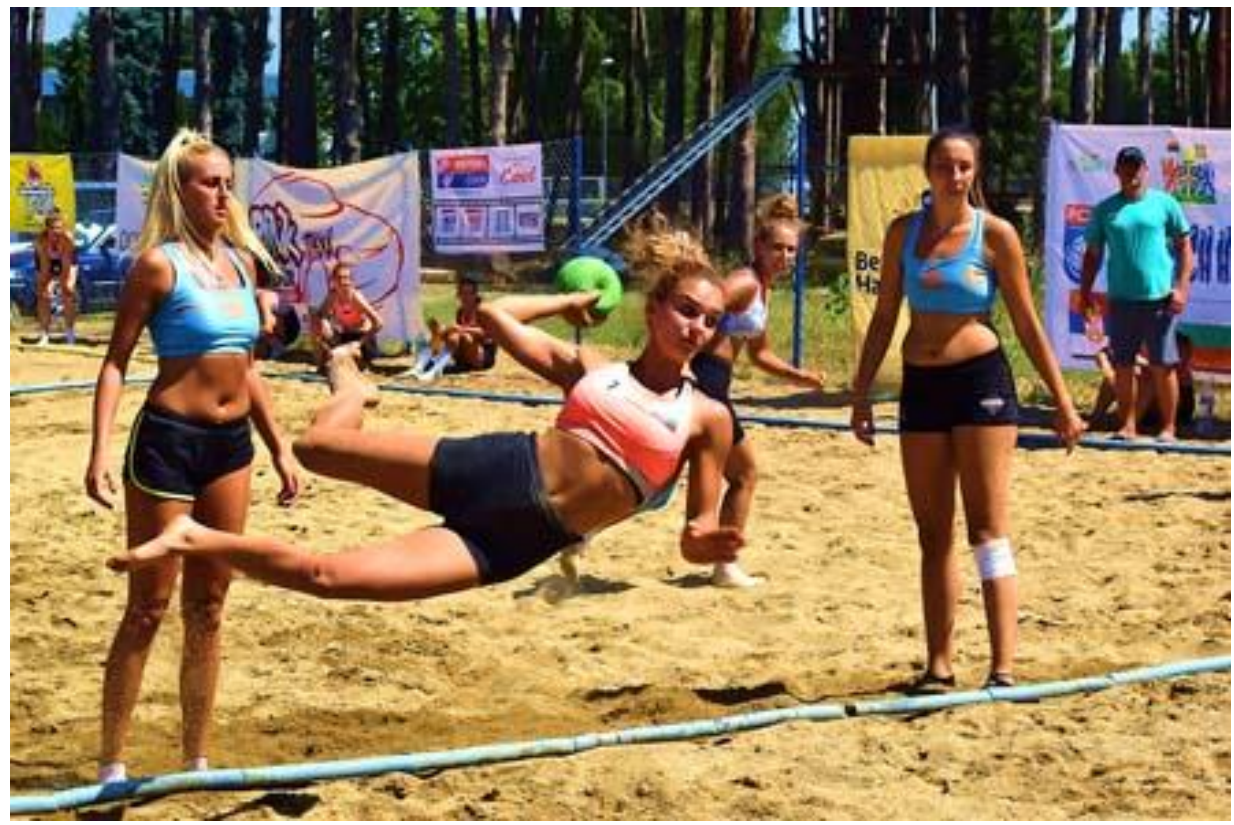

Legend: Artistic representation of handball: An attempt to perform an eret on the sand: Photo: Miloš Stamenković.

Beach handball is an attractive variant of handball for sports photography and photojournalists. Unlike indoor handball, beach handball is played in outdoor space, which means that the possibility of getting a quality photograph is higher. The possibility is higher due to natural light and the reduced value of the ISO parameter. Whenever handball is played in the hall, the ISO value increases due to poor lighting. The higher its value, the greater the chance that the quality of the captured photographs will deteriorate. Analyzing this image, it can be noticed that the light is strong and that the handball player creates a shadow on some part of the face. This means that this kind of light is not ideal for photographing sports events and other manifestations.

The best light is achievd with the help of clouds, because it is then soft and sharp enough. In any case, this photograph meets all criteria and elements of a goot photograph (composition, light, dynamics, contrast).

\section{CONCLUSION}

Based on all the above, it can be concluded that sports photography is an artistic experience of sports and sports events. Through sports photography, 
athletes are presented as creators, i.e. artists, who with their motor skills present sport as art. Sports photography shows moving actions as artistic, because different body positions at different angles, with rotations and muscle contractions, are seen that way. When a movement is caught in action, it is inevitably a movement that unites both art and science.

From the artistic aspect, the movement posture is analyzed, while from the scientific aspect, the mechanical properties of muscles, physiological propertis of the organism and neurological properties of CNS are analyzed, as well as the influence of the CNS on the production of movement. Sports photography is a powerful visual tool that can be used to promote regular physical activity. In other words, good sports photography can move a person to engage in physical activity not for the sake of results, but for the sake of health.

In any case, sports photography plays a very important role in promoting not only professional and recreational sports, but also healthly lifestyles through recreational physical activity. Sports photojournalists play a very important role in promoting sports and recreational physical activity. By analyzing the photographs shown in this paper, it can be concluded that it is not easy to make a good sports photograph. On the other hand, the satisfaction is greater when a good sports photograph is taken and when it can be used in the promotion of sports and recreational physical activity. Through sports photography, sport is more than sport, sport is art. It is necessary to continue with the theoretical analysis of sports photography, in order to better understand it.

\section{REFERENCES}

1. Живановић Ненад, Ранђеловић Небојша, Станковић Верољуб \& Петровић Павле. Теорија физичке културе. Штампа: Мкопс, Ниш, 2010.

2. Stamenković, Miloš. Sports photography and historical development. Fizičko vaspitanje i sport kroz vekove, 2018, 5.1: 93-115.

3. https://en.wikipedia.org/wiki/Sports_photography.

\section{СПОРТИВНАЯ ФОТОГРАФИЯ И ЕЕ ХУДОЖЕСТВЕННАЯ МНОГОМЕРНОСТЬ}

\footnotetext{
АННОТАЦИЯ

Спортивная фотография - это мощный визуальный инструмент, который можно использовать для популяризации спорта, спортсменов и оздоровительных физических занятий. Ее главная роль - представить спорт как искусство. В этом отношении хорошая спортивная фотография также
} 
подразумевает запечатленный момент спортсмена в специфической позе движения, которая необычна и которую невозможно увидеть по телевизору. Когда речь идет о популяризации профессионального спорта, спортивная фотография занимает важное место в спортивной прессе и спортивных журналах. С другой стороны, спортивная фотография также продвигает рекреационный спорт, который предназначен для всех тех, кто хочет заниматься спортом для себя и своего здоровья. Спортивная фотография способна представить читателям важные спортивные и рекреационные события в простой форме, без больших и сухих текстов. Хорошая спортивная фотография подразумевает композицию, ракурс, свет, динамику и цветовой контраст, то есть соотношение между теплыми и холодными тонами. Также спортивная фотография зависит от хорошего фотооборудования, знаний и опыта спортивного фотожурналиста. Спортивные фотожурналисты всегда стараются наиболее профессионально и качественно представить интересные спортивные фотографии, которые в художественной форме доносят "визуальную информацию" о спортивных событиях до преданных читателей и спортивных болельщиков. Очень важно понимать, что спортивная фотография - это не только спорт, но и искусство. Поэтому цель данной статьи - представить спортивную фотографию и ее художественное измерение.

Ключевые слова: спортивная фотография, искусство, фотожурналист, рекреационная деятельность, спорт, спортивная пресса, многомерность. 